Ethiopian Journal of Environmental Studies \& Management 9 (1): 70 - 79, 2016.

ISSN:1998-0507

Submitted: August 21, 2015

doi: http://dx.doi.org/10.4314/ejesm.v9i1.7

Accepted: January 12, 2016

\title{
INVESTIGATION OF THE INFLUENCE OF ATLANTIC OCEAN ON RAINFALL VARIABILITY OVER BENIN REPUBLIC, WEST AFRICA
}

\author{
OGOU, F.K.1 , BATEBANA, K.1 , OGWANG, B.A. ${ }^{1,2}$, SEIN, Z.M.M.1,3, *ONGOMA, V.1,4 AND \\ NGARUKIYIMANA, J.P. 1 \\ ${ }^{1}$ College of Atmospheric Sciences, Nanjing University of Information Science and \\ Technology, Nanjing, Jiangsu, 210044, P.R. China \\ ${ }^{2}$ Uganda National Meteorological Authority, P.O. Box 7025, Kampala, Uganda \\ ${ }^{3}$ Department of Meteorology and Hydrology, Myanmar \\ ${ }^{4}$ Department of Meteorology, South Eastern Kenya University, P.O. Box 170-90200, Kitui, \\ Kenya
}

\begin{abstract}
This study investigates the contribution of Atlantic Ocean to the seasonal rainfall over Benin using Singular Value Decomposition (SVD) and correlation. The rainfall over the country is mainly unimodal, experienced in the months of June to September (JJAS). The SVD analysis on the anomalous JJAS rainfall and anomalous Sea Surface Temperature (SST) in the Atlantic Ocean reveals two dominant coupled modes. The first couple mode that dominates the covariability between the anomalous rainfall and the SST reveals positive covariability between anomalous rainfall in central Benin and anomalous SST in central Atlantic. The second couple mode that dominates the covariability between the anomalous rainfall and the SST reveals positive covariability between anomalous SST in central Atlantic and anomalous rainfall in northern Benin to be negative and to be positive to anomalous rainfall in the southern Benin. Generally, the correlation between rainfall over Benin and sea surface temperature over Atlantic Ocean is high and positive. Analysis shows that the years 1988, 1989, 2003, 2007 and 2008, were wet while the years 1982, 1983, 1984, 1986 were dry. The moist southwesterly air dominated the country during wet years. The country was characterized by dry northeasterly air during the dry years. Close observation of the evolution of sea surface temperature over Atlantic Ocean and wind flow over Benin is recommended, in the seasonal forecasting and updating of the forecast.
\end{abstract}

Key Words: Rainfall, SVD, Atlantic Ocean, Benin

\section{Introduction}

Benin is located in West Africa (WA), on the Guinea Coast. The country is confined within latitude $6.2^{\circ}-13^{\circ} \mathrm{N}$ and longitude $0.7^{\circ}-4^{\circ} \mathrm{E}$ as shown in Figure 1 . Rain fed agriculture is the main stay of Benin; it had employed about $45 \%$ of active population and contributes to over $35 \%$ of Gross Domestic Product (GDP) (Gangnibo et al., 2010). The overdependence on rain fed agriculture thus makes rainfall the most important weather element in Benin and the entire West African region. Rainfall variability in

*Corresponding Author: Ongoma, V.

Email: victor.ongoma@gmail.com 
the region is associated with huge socioeconomic losses (Abiodun et al., 2008; Nicholson et al., 2000).

The climate of Benin is tropical; it is strongly influenced by the West African Monsoon (WAM) (McSweeney et al., 2010). The rainfall seasons of Benin are controlled by the meridional march of the Inter-Tropical Conversion Zone (ITCZ), which oscillates between the northern and southern tropics over the course of a year (McSweeney et al., 2010). According to McSweeney et al. (2010), the dominant wind direction in regions south of the ITCZ is southwesterly, blowing moist air from the Atlantic onto the continent, but north of the ITCZ, the prevailing winds come from the north east, bringing hot and dusty air from the Sahara desert; 'Harmattan'.

According to Dai et al. (2004), most states in the West African area, are recording continuous rainfall deficit since the beginning of the 1970s. The rainfall deficit is characterized by extreme rainfall events that are associated with loss of lives and destruction of property in Benin. Studies (e.g. Sultan and Janicot, 2000; Le Barbe et al., 2002; Redelsperger et al., 2002) have observed that major intense rainfall events appear in the Gulf of Guinea from April, move to the latitudes of about $10^{\circ} \mathrm{N}$ during the boreal summer, and then retreat back to the south after midSeptember-October. Benin experiences relatively cool and humid monsoon air mass originating from the Gulf of Guinea, and the hot-dry and dusty Saharan air mass alternatively. The boundary between the two air masses is known as the InterTropical Front (ITF) (Hamilton et al., 1945; Fink et al., 2010). Maloney and Shaman (2008) studied rainfall characteristics using composite analysis and complex empirical orthogonal function analysis and found that 30-90 days precipitation anomalies are generally zonally-elongated, grow and decay in place, and have maximum amplitude in the Gulf of Guinea and the Atlantic. The study further observed that enhanced precipitation events are associated with a significant weakening of north Atlantic trade winds, and suppressed precipitation events are accompanied by significant enhancement of the trades. The amplitude of 30-90 days precipitation variability varies greatly from summer to summer, with some years exhibiting strong variability, and other years having very weak variability (Maloney and Shaman, 2008). Studies have been done over the entire WA region which may not capture the local phenomenon.

This calls for more understanding of the rainfall variability over Benin in relation with Atlantic Ocean. This study employs the SVD technique to address two questions. First, what is the contribution of Atlantic Ocean on the observed rainfall over Benin? Second, does the individual dominant mode in anomalous rainfall in Benin during June - September period represents dominant coupled mode variability? 


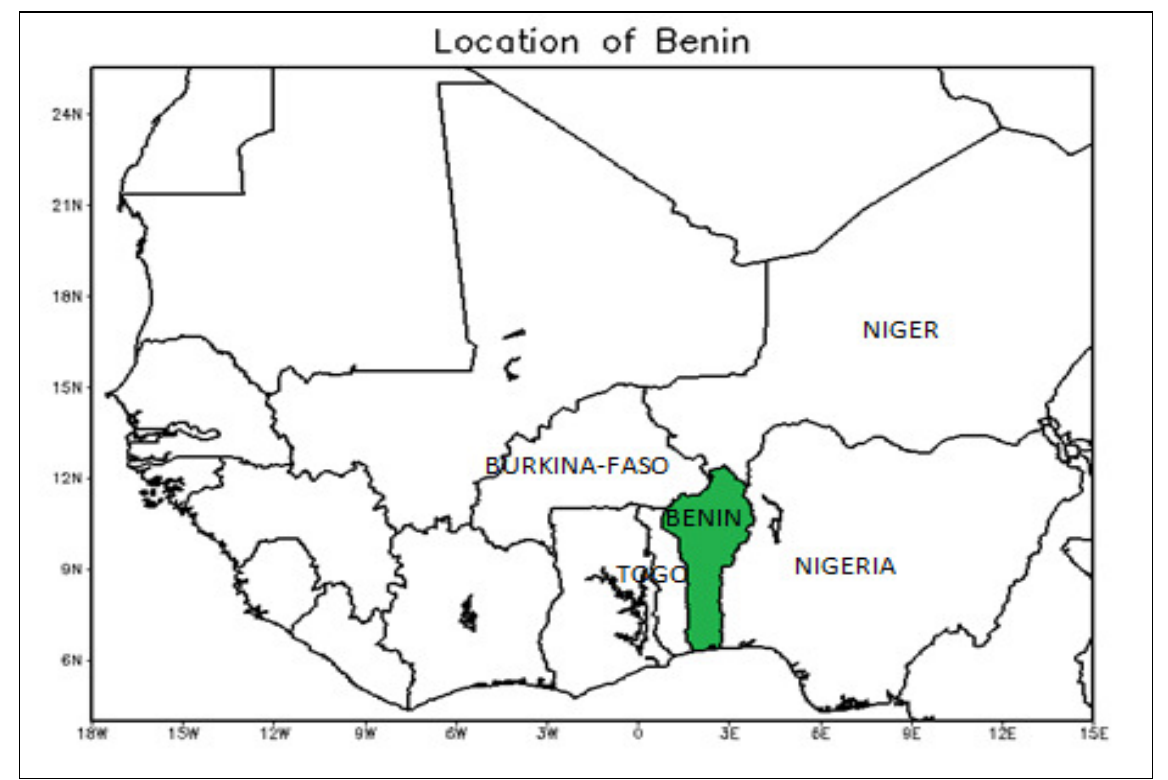

Figure 1: Map of the Benin Republic (shaded in green)

\section{Methodology}

\section{Data}

The study utilized reanalyzed rainfall data for 30 years. This study only considered rainfall behavior in the months of June - September. The reanalyzed monthly precipitation data spanning from 1981 to 2010 was obtained from Global Precipitation Climatology Centre (GPCC). GPCC provides precipitation data sets from 1901 to present, calculated from the global station data (Schneider et al., 2013). The GPCP version 2.2 combined precipitation dataset, gridded at 2.5 degree resolution (Adler et al., 2003; Huffman et al., 2011) is provided by the NOAA/OAR/ESRL PSD, Boulder, Colorado, USA, from their Web site at http://www.esrl.noaa.gov/psd/. The data was successfully used in recent studies by Sein et al. (2015) over Mynmar and Ogwang et al. (2015) over East Africa.

The SST data used is the Extended Reconstructed Sea Surface Temperature (ERSST) version3b from the National Oceanic and Atmospheric Administration (NOAA)/National Climatic Data Center
(Smith et al., 2008), available in their website at

http://iridl.ldeo.columbia.edu/SOURCES/. NOAA/.NCDC/.ERSST/.version3b/.sst/ .

Reanalysis data; meridional and zonal winds used to determine airflow were sourced from ERA-interim reanalysis, gridded at 0.75 degree resolution for 850 $\mathrm{hPa}$ level. The data is adequately discussed by Dee et al. (2011).

\section{Analytical Technique}

The singular value decomposition technique (SVD) is used to analyze the covariability between anomalous June September rainfall in Benin and the largescale anomalous sea surface temperature (SST) in Atlantic Ocean. SVD technique is a generalization to the square symmetric matrix diagonalization technique such as the empirical orthogonal function (EOF) analysis. This technique is applied to two data sets of two jointly analyzed fields to identify pairs of the coupled spatial pattern and their respective temporal variations. Each pair explains a degree of covariance between the two jointly analyzed fields. The decomposition allows the extraction of dominant modes of coupled covariability 
between the two analyzed fields. The technique has been successfully applied in previous studies (e.g. Juneng and Tangang, 2006; Tangang, 1999; Venegas et al., 1996).

Correlation analysis was employed to reveal the simple relationships between two variables (Wilks, 2006); JuneSeptember rainfall over the study area and SST over Atlantic Ocean.

\section{Results and Discussion}

Benin and the larger West Africa region receive unimodal rainfall. The rainfall is witnessed in the months of June - September (JJAS) (Figure 2). The observation is in agreement with the findings of other studies (e.g. McSweeney et al., 2010; Sultan and Janicot, 2000). The rainfall is rainfall is mainly influenced by the seasonal march of ITCZ; it coincides with the northern hemisphere summer and the West Africa Monsoon; the prevailing wind is south-westerly. Dry season is observed between December and March, during this period, the 'Harmattan' wind; north-easterly, blows. Sultan and Janicot (2000), reported that maximum rainfall associated with West Africa Monsoon (WAM) is reported in the northernmost locations in August and then withdraws southwards during September, but continues to October. Similarly, Xue et al. (2010) describes the months of June, July, August, and September as the major WAM season.

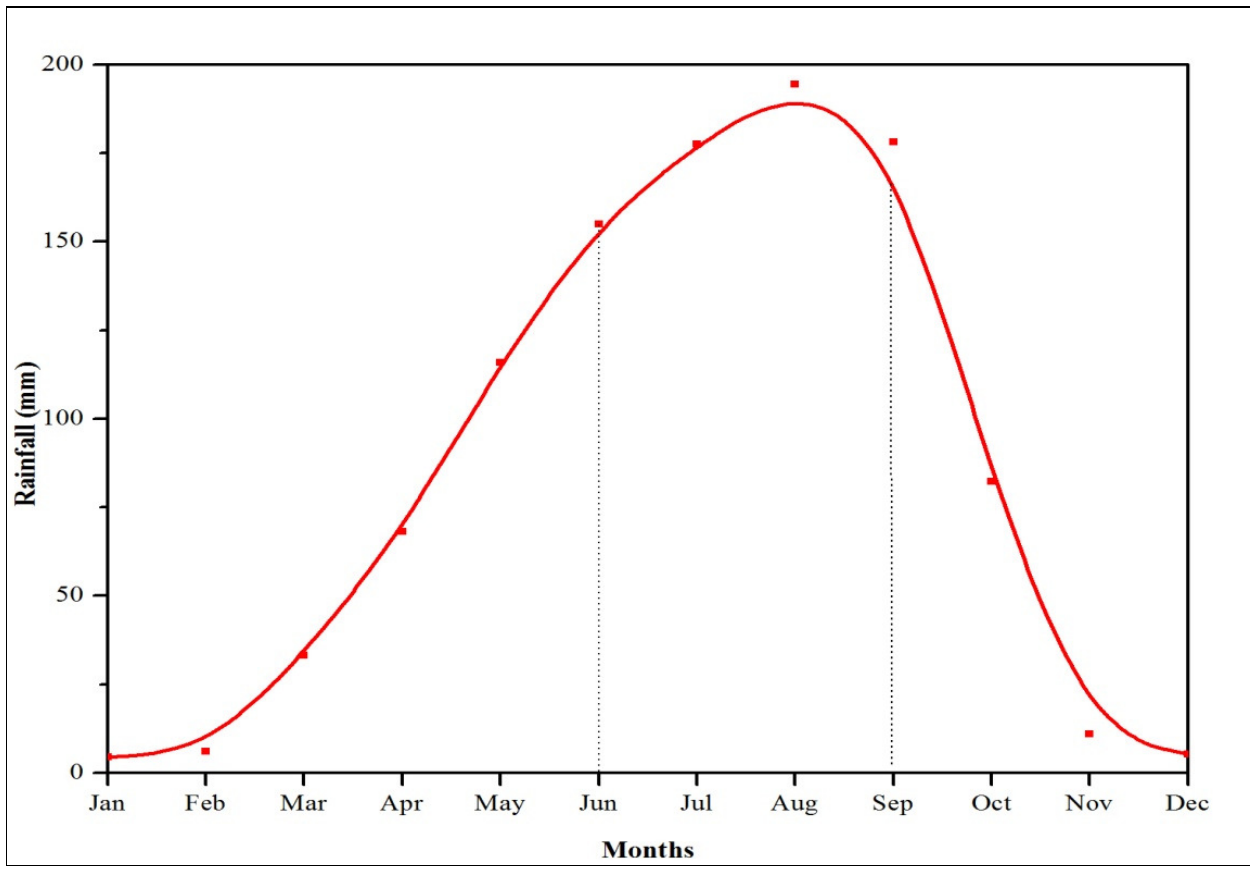

Figure 2: Mean monthly rainfall over Benin (1981-2010)

The cumulative Squared Covariance Fraction (SCF) for the first three modes was above $90 \%$. According to Newman and Sardeshmukh (1995), if the leading three modes explain a significant (greater than $80 \%$ ) amount of the variance between the two fields, then SVD can be applied to determine the strength of the coupled variability present. 
The results of this study show for the season June-September a higher cumulative percentage square covariance of the first two modes $(91.06 \%$ of the total). The first two modes of SVD are then used in this study to have deeper knowledge about the rainfall variability.

Figures 3 and 4 show the covariability between anomalous sea surface temperature over Atlantic Ocean and anomalous rainfall over Benin. The SVD analysis on the anomalous June-September rainfall and anomalous SST in the Atlantic Ocean reveals two dominant coupled modes. The first couple mode that dominates the covariability between the anomalous June-September rainfall and the SST reveals positive covariability between anomalous rainfall in central Benin and anomalous SST in central Atlantic. The second couple mode that dominates the covariability between the anomalous JuneSeptember rainfall and the SST reveals positive covariability between anomalous SST in central Atlantic and anomalous rainfall in northern Benin to be negative and to be positive to anomalous rainfall in the southern Benin.

The temporal amplitude for rainfall and the SST correlate each other very well $(>0.7)$, indicating the coupled nature of the relationship.

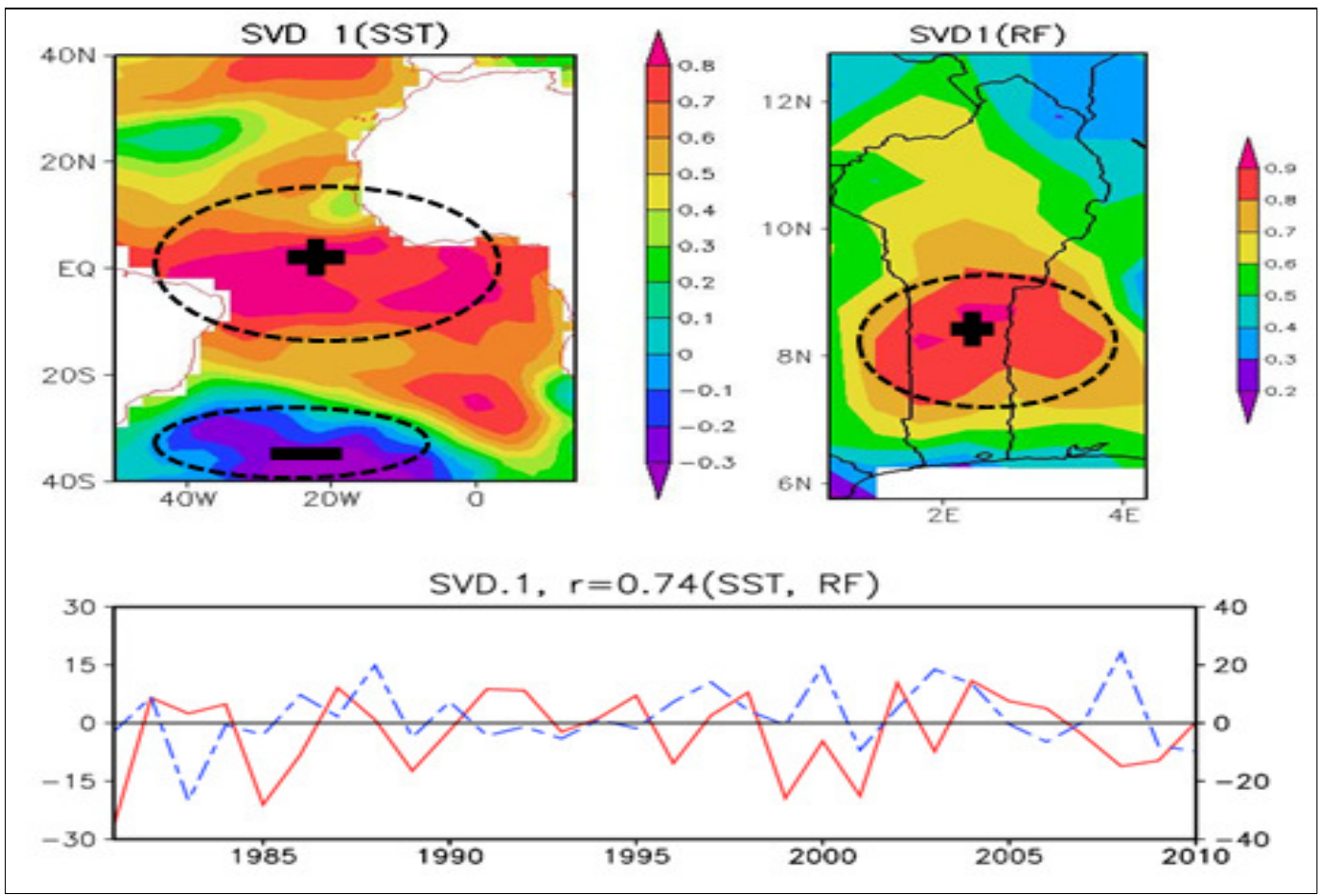

Figure 3: The homogenous maps for the first dominant coupled mode, (above left) anomalous SST pattern (above right) anomalous rainfall pattern, (bottom), Temporal amplitude of anomalous rainfall for the first dominant coupled mode [The dotted line represents the time series of rainfall oscillation and the solid line in red that of sea surface temperature] 


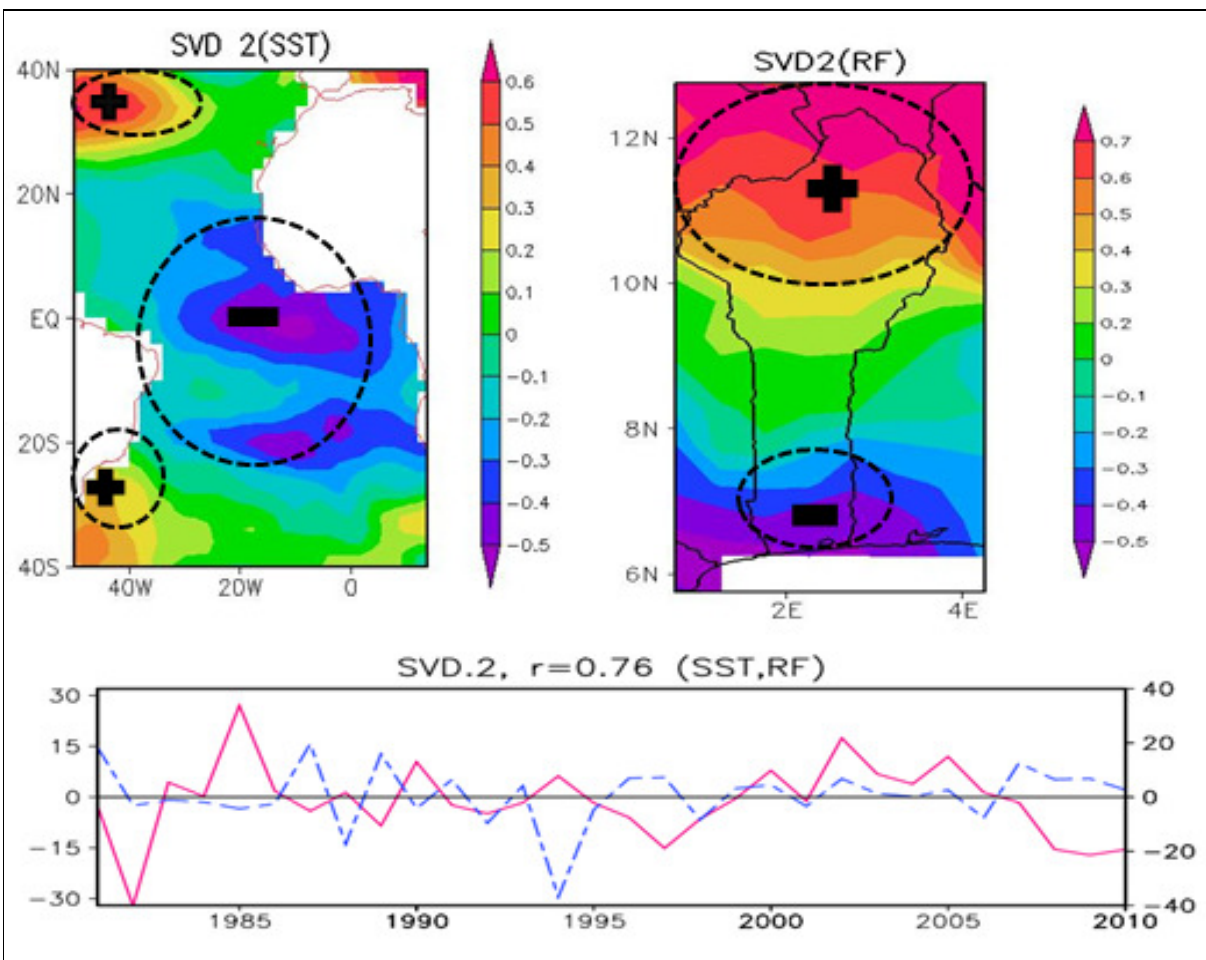

Figure 4: The homogenous maps for the second dominant coupled mode, (above left) anomalous SST pattern (above right) anomalous rainfall pattern, (bottom) Temporal amplitude of anomalous rainfall for the first dominant coupled mode [The dotted line represents the time series of rainfall oscillation and the solid line in red that of sea surface temperature]

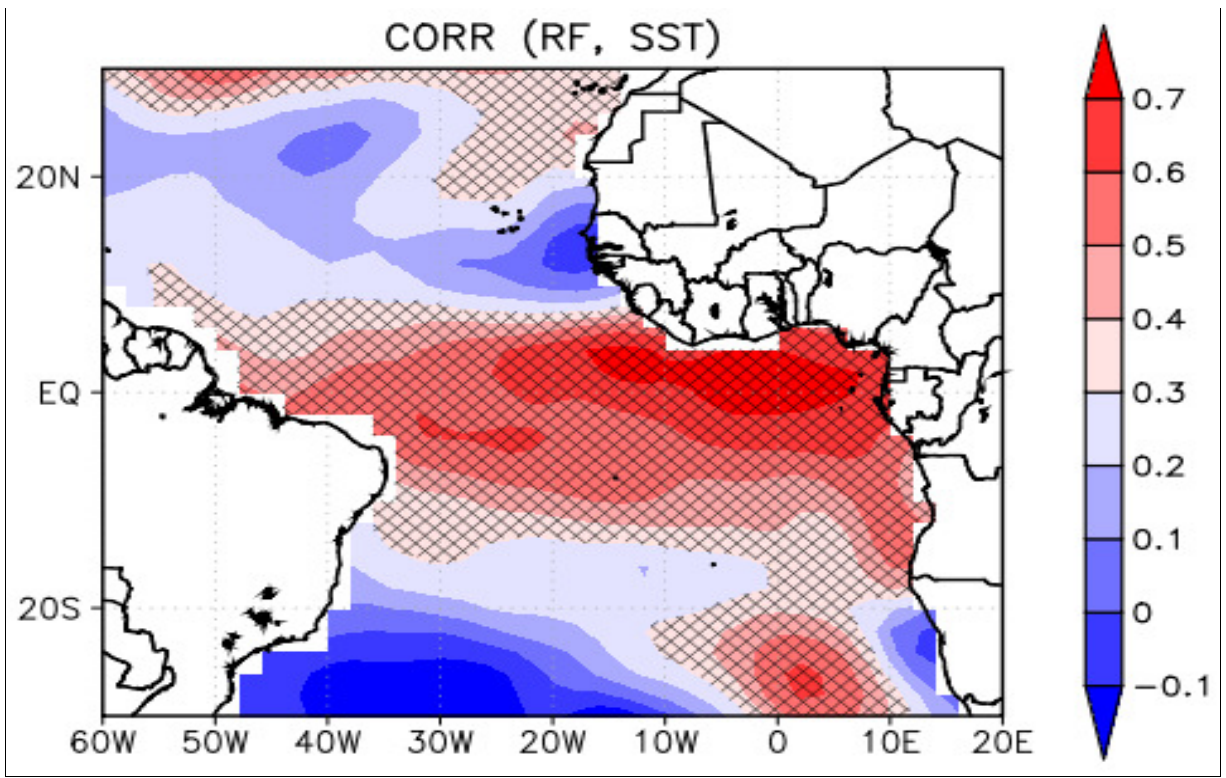

Figure 5: Spatial map of correlations of rainfall (RF) and SST (The hatched areas show the zones where the correlations between SST and RF are significant at threshold of 5\% (i.e. p < $0.05)$. 
Figure 5 shows spatial correlation between sea surface temperature (SST) and rainfall (RF). Two faces are shown through this map where the rainfall over the country is highly positively correlated with the sea surface temperature. Increase in sea surface temperature in the Atlantic Ocean, in the Gulf of Guinea, is leads to enhanced rainfall over Benin.

McSweeney et al. (2010) observed that annual rainfall in Benin is highly variable on inter-annual timescales. The standardized anomaly of the rainfall over time period of 1981-2010 is shown in Figure 6. The years that recorded standardized rainfall anomaly values of above $\geq 1$ and below $\leq-1$ are defined as wet and dry years respectively. The same categorization has been employed in different studies globally e.g. Ogwang et al. (2015) over East Africa and Tan et al. (2014) over China. The years 1988, 1989, 2003, 2007 and 2008, fall in the wet year category while the years 1982, 1983, 1984, 1986 were classified under dry years. Focusing on the selected dry and wet years, analysis of winds; wind circulation anomaly was carried out to get the atmospheric circulations associated with extreme weather events.

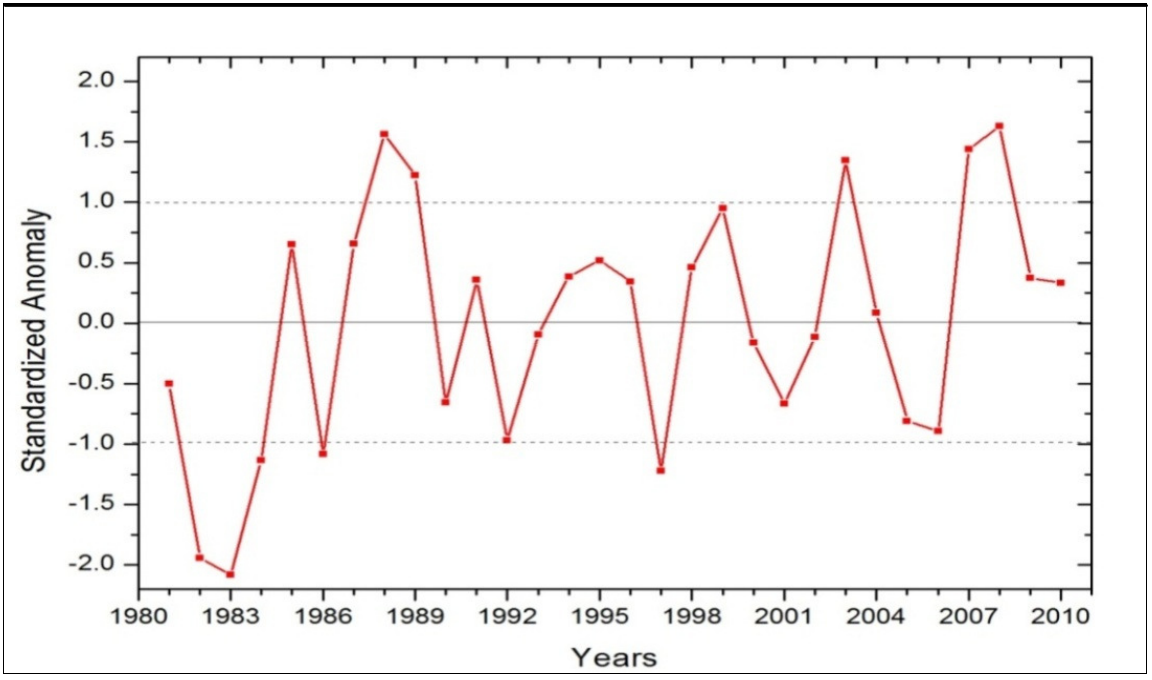

Figure 6: Time series of standardized anomaly of rainfall from 1981 to 2010

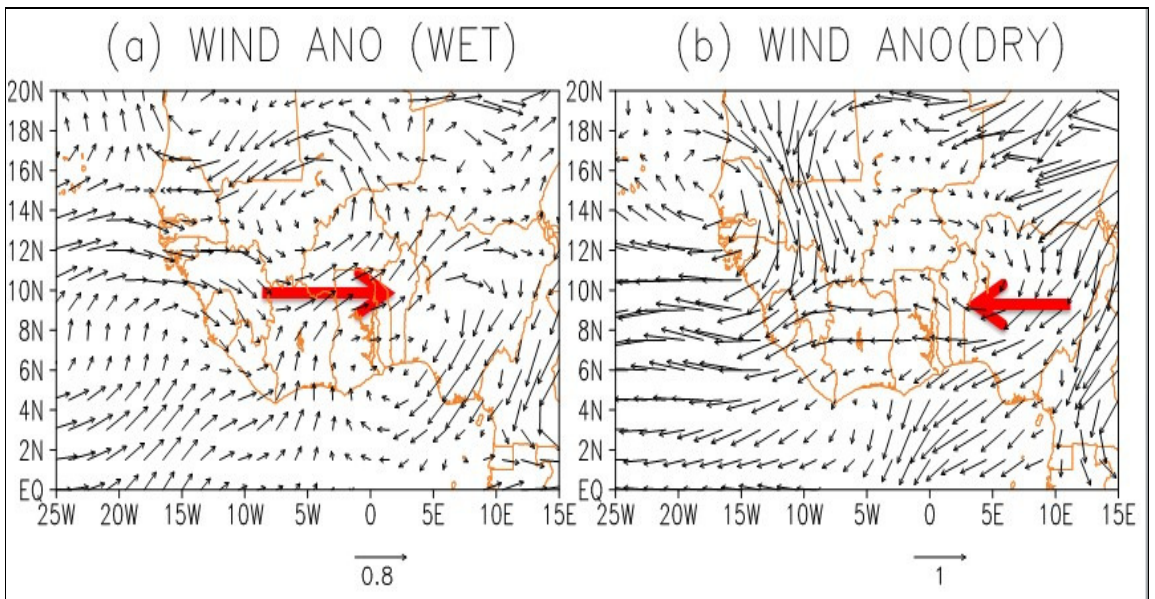

Figure 7: Winds circulations anomaly over Benin at $850 \mathrm{hPa}$ 
Figure 7 gives a display of wind circulation anomaly during wet and dry years. During wet years, the wind flow is mainly southwesterly over Benin. The wind flowing inland from the Atlantic Ocean is generally warm and moist. The wind components; the $u$ and $v$ components of anomalous $850 \mathrm{hPa}$ winds indicate a weaker anomalous cyclonic circulation during wet years that favour rainfall formation. The prevailing winds during wet years known to favour rainfall formation owing to moisture fetch and weakness hence the observed wet events. The situation reverses during dry years; dry and dusty northeasterly wind dominates over the country, limiting the occurrence of convective activities.

\section{Conclusion and Recommendation}

Understanding rainfall variability and factors controlling it is very important. This study investigates the contribution of Atlantic Ocean to the June - September seasonal rainfall over Benin. SVD 1 and SVD 2 explain more than $90 \%$ of the covariability of rainfall over Benin and sea surface temperature over the Atlantic Ocean. The SVD analysis on the anomalous June-September rainfall and anomalous SST in the Atlantic Ocean reveals two dominant coupled modes. There is observed high positive correlation exhibited by correlation coefficient of more than 0.7 between rainfall over Benin and sea surface temperature over the Atlantic Ocean. The years 1988, 1989, 2003, 2007 and 2008, were wet while the years 1982, 1983, 1984 and 1986 formed the dry years. The moist southwesterly air dominated the country during wet years as opposed to the dry northeasterly air during the dry years. The study recommends monitoring of the evolution of sea surface temperature over Atlantic Ocean and wind flow over Benin can be of great importance in the update of seasonal weather forecast.

\section{Acknowledgements}

The authors express their sincere appreciation to Nanjing University of Information Science and Technology (NUIST) for creating a research enabling environment. Special appreciation goes to Global Precipitation Climatology Centre (GPCC), National Oceanic and Atmospheric Administration (NOAA) and ERA-Interim's European Centre for Medium-Range Weather Forecasts (ECMWF) for providing data used in this study. The first author gives special thanks to World Meteorological Organization (WMO) for sponsoring his Master (Meteorology) study in China.

\section{References}

Abiodun, B.J., Pal, J.S., Afiesimama, E.A., Gutowski, W.J. and Adedoyin, A. (2008). Simulation of West African monsoon using RegCM3 part II: impacts of deforestation and desertification. Theoretical and Applied Climatology, 93: 245 - 261. doi:10.1007/s00704-007-0333-1

Adler, R.F., Huffman, G.J., Chang, A., Ferraro, R., Xie, P., Janowiak, J., Rudolf, B., Schneider, U., Curtis, S., Bolvin, D., Gruber, A., Susskind, J. and Arkin, P. (2003). The Version 2 Global Precipitation Climatology Project (GPCP) Monthly Precipitation Analysis (1979Present). Journal of Hydrometeorology, 4: 1147 - 1167. doi: http://dx.doi.org/10.1175/15257541(2003)004<1147:TVGPCP >2.0. $\mathrm{CO} ; 2$

Dai, A., Lamb, P.J., Trenberth, K.E., Hulme, M., Jones, P.D. and Xie, P. 
(2004). The recent Sahel drought is real. International Journal of Climatology, 24: 1323 - 1331. DOI: $10.1002 /$ joc. 1083

Dee, D.P., Uppala, S.M., Simmons, A.J., Berrisford, P., Poli, P., Kobayashi, S., Andrae, U., Balmaseda, M.A., Balsamo, G., Bauer, P., Bechtold, P., Beljaars, A.C.M., van de Berg, L., Bidlot, J., Bormann, N., Delsol, C., Dragani, R., Fuentes, M., Geer, A.J., Haimberger, L., Healy, S.B., Hersbach, H., Hólm, E.V., Isaksen, L., Kållberg, P., Köhler, M., Matricardi, M., McNally, A.P., Monge-Sanz, B.M., Morcrette, J.J., Park, B.K., Peubey, C., de Rosnay, P., Tavolato, C., Thépaut, J.N. and Vitart, F. (2011). The ERA-Interim reanalysis: configuration and performance of the data assimilation system. Quarterly Journal of Royal Meteorological Society, 137: 553597. doi: 10.1002/qj.828.

Maloney, E.D. and Shaman, J. (2008). Intraseasonal Variability of the West African Monsoon and Atlantic ITCZ. Journal of Climate, 21: 2898- 2918. DOI: 10.1175/2007JCLI1999.1

Fink, A.H., Paeth, H., Ermert, V., Pohle, S. and Diederich, M. (2010). Meteorological processes influencing the weather and climate of Benin. In: Impacts of Global Change on the Hydrological Cycle in West and Northwest Africa. Springer, DOI: $10.1007 / 978-3-642-12957-5$

Gangnibo, C.N., Cheng, S., Huang, L. and Sambou, A. (2010). Sustainable agriculture in Benin: strategies for applying the chinese circular agriculture model. Journal of Sustainable Development, 3: 69-80. DOI: 10.5539/jsd.v3n1p69

Hamilton, R.A., Archbold, J.W. and Douglas, C.K.M. (1945).
Meteorology of Nigeria and adjacent territory. Quarterly Journal of Royal Meteorological Society, 71: 231-262. doi: 10.1002/qj.49707130905

Huffman, G.J., Bolvin, D.T. and Adler, R.F. (2011). GPCP Version 2.2 Combined Precipitation Data set, WDC-A, NCDC, Asheville, NC.

Juneng, L. and Tangang, F.T. (2006). The covariability between anomalous northeast monsoon rainfall in Malaysia and sea surface temperature in Indian-Pacific sector: A Singular Value Decomposition Analysis approach. Journal of Physical Sciences, 17: 101-115

Le Barbe L., Lebel T. and Tapsoba, D. (2002). Rainfall Variability in West Africa during the Years 1950-90. Journal of Climate, 15: 187 - 202. doi: http://dx.doi.org/10.1175/15200442(2002)015<0187:RVIWAD $>2.0$ . $\mathrm{CO} ; 2$

McSweeney, C., Lizcano, G., New, M. and Lu, X. (2010). The UNDP Climate Change Country Profiles. Bulletin of American Meteorological Society, 91: $\quad$ 157-166. doi: http://dx.doi.org/10.1175/2009B AMS2826.1

Newman, M. and Sardeshmukh, P.D. (1995). A caveat concerning singular value decomposition. Journal of Climate, $8352 \quad-\quad 360$. doi: http://dx.doi.org/10.1175/15200442(1995)008<0352:ACCSVD $>2.0$. $\mathrm{CO} ; 2$

Nicholson, S.E., Some, B. and Kone, B. (2000). An analysis of recent rainfall conditions in West Africa, including the rainy seasons of the 1997 El Niño and the 1998 La Niña years. Journal of Climate, 13: 2628 - 2640. doi: http://dx.doi.org/10.1175/15200442(2000)013<2628:AAORRC $>2.0$ . $\mathrm{CO} ; 2$ 
Ogwang, B.A, Ongoma, V., Xing, L. and Ogou, F.K. (2015). Influence of Mascarene High and Indian Ocean Dipole on East African Extreme Weather Events. Geographica Pannonica, 19: 64-72

Redelsperger, J.L., Diongue, A., Diedhiou, A., Ceron, J.P., Diop, M., Gueremy, J.F. and Lafore, J.P. (2002). Multiscale description of a Sahelian synoptic weather system representative of the West African monsoon. Quarterly Journal of Royal Meteorological Society, 128: 1229 1257.

DOI: $10.1256 / 003590002320373274$.

Schneider, U., A. Becker, P. Finger, A. Meyer-Christoffer, M. Ziese, and B. Rudolf, 2013. GPCC's new land surface precipitation climatology based on quality-controlled in situ data and its role in quantifying the global water cycle. Theoretical and Applied Climatology, 115: 15 - 40. DOI: 10.1007/s00704-013-0860-x

Sein, Z.M.M., Ogwang, B.A., Ongoma, V., Ogou, F.K. and Batebana, K. (2015). Inter-annual variability of summer monsoon rainfall over Myanmar in relation to IOD and ENSO. Journal of Environmental and Agricultural Sciences, 4: 28 - 36.

Smith, T.M., Reynolds, R.W., Peterson, T.C. and Lawrimore, J. (2008). Improvements to NOAA's Historical Merged Land-Ocean Surface Temperature Analysis (1880-2006). Journal of Climate, 21: 2283 - 2296. doi: http://dx.doi.org/10.1175/2007J CLI2100.1

Sultan, B. and Janicot, S. (2000). Abrupt shift of the ITCZ over West Africa and intra-seasonal variability.
Geophysical Research Letters, 27: 3353 3356.

DOI: $10.1029 / 1999 G L 011285$

Tan, G.-R, Ren, H.-L. and Chen, H. (2014). Quantifying synoptic eddy feedback onto the low-frequency flow associated with anomalous temperature events in January over China. International Journal of Climatology, 35: 1976-1983. DOI: 10.1002/joc. 4135

Tangang, F.T. (1999). Empirical orthogonal function analysis of precipitation anomaly in Malaysia. Malaysian Journal of Analytical Science, 5: 155-165.

Venegas, S.A., Mysak, L.A. and Straub, D.N. (1996). Evidence for interannual and interdecadal climate variability in the South Atlantic. Geophysical Research Letters, 23: 2673 2676.

DOI: 10.1029/96GL02373

Wilks, S.D. (2006). Statistical Methods in the Atmospheric Sciences. $2^{\text {nd }}$ Edn, Academic Press, San Diego

Xue, Y., Sales, F., Lau, W.K.M., Boone, A., Feng, J., Dirmeyer, P., Guo, Z., Kim, K.M., Kitoh, A., Kumar, V., Poccard-Leclercq, I., Mahowald, N., Moufouma-Okia, W., Pegion, P., Rowell, D.P., Schemm, J., Schubert, S.D., Sealy, A., Thiaw, W.M., Vintzileos, A., Williams, S.F. and Wu, M.L.C. (2010). Intercomparison and analyses of the climatology of the West African Monsoon in the West African monsoon modeling and evaluation project (WAMME) first model intercomparison experiment. Clim Dyn., 35:3-27. doi:10.1007/s00382-010-0778-2 